\title{
O DOCUMENTO DA COMISSÃO TEOLÓGICA INTERNACIONAL SOBRE O SENSUS FIDEI
}

\author{
THE DOCUMENT OF THE INTERNATIONAL THEOLOGICAL \\ COMMISSION ABOUT SENSUS FIDEI
}

\section{Geraldo Luiz Borges Hackmann*}

\section{RESUMO}

O artigo faz uma resenha do documento $O$ sensus fidei na vida da Igreja, publicado pela Comissão Teológica Internacional, em 2014. Por fim, analisa sua novidade e apresenta alguns aspectos a serem aprofundados na sua recepção pela vida eclesial e, particularmente, pela Teologia.

Palavras-chave: Sensus fidei. Sensus fidelium. Igreja. Comissão Teológica Internacional.

\section{ABSTRACT}

This article makes a review of the document The sensus fidei in the Church's life, published by the International Theological Commission, in 2014. Finally, it analyses its novelty and presents some aspects to be further developed in its reception by the ecclesial life and, particularly, by Theology.

Keywords: Sensus fidei. Sensus fidelium. Church. International Theological Commission.

* Doutor em Teologia, professor da Faculdade de Teologia da Pontifícia Universidade Católica do Rio Grande do Sul e membro da Comissão Teológica Internacional. E-mail: <gborgesh@pucrs.br>.

\begin{tabular}{|l|l|l|l|l|l|}
\hline Teocomunicação & Porto Alegre & v. 45 & n. 2 & p. 117-135 & maio-ago. 2015 \\
\hline
\end{tabular}




\section{Introdução}

A Congregação para a Doutrina da Fé pediu à Comissão Teológica Internacional, em sua sessão de 2011, para refletir e, posteriormente, preparar um documento sobre o sensus fidei e sensus fidelium. ${ }^{1} \mathrm{O}$ motivo do pedido foi a necessidade de a Congregação apresentar uma reflexão sobre este tema, que se tornou importante pela ênfase que recebeu no Concílio Ecumênico Vaticano II, no número 12 da Constituição Dogmática Lumen Gentium. ${ }^{2}$ O Documento afirma: "O Concílio ensinou que todos os batizados participam, cada um a seu modo, dos três ofícios de Cristo: profeta, sacerdote e rei. Em particular, ele ensinou que Cristo cumpre o seu papel profético não só através da hierarquia, mas também por meio dos leigos" e descartou "a representação distorcida de uma hierarquia ativa e um laicato passivo e, particularmente, a noção de uma rigorosa separação entre a Igreja docente (Ecclesia docens) e a Igreja discente (Ecclesia discens)". ${ }^{3}$

$\mathrm{O}$ documento foi redigido em quatro capítulos. O primeiro dedica-se, inicialmente, à fundamentação bíblica, para, depois, fazer uma retrospectiva histórica, da idade patrística até o século XX. O segundo aborda a manifestação do sensus fidei na vida pessoal do fiel, mostrando-o como "instinto da fé". O terceiro analisa os vários aspectos do sensus fidei fidelium na vida da Igreja, iniciando pelos aspectos retrospectivos

1 Para tal, foi indicada uma subcomissão, constituída pelos seguintes membros: Mons. Paul McPartlan (Presidente); Pe. Serge-Thomas Bonino, OP (Secretário Geral); Irmã Sara Butler, MSBT; Pe. Antonio Castellano, SDB; Pe. Adelbert Denaux, Pe. Tomislav Ivancic; Excia. Rev. Dom Jan Liesen; Pe. Leonard Santedi Kinkupu; Prof. Thomas Söding e Pe. Jerzy Szymik. O documento foi concluído em 2014 e foi aprovado pela maioria dos membros da Comissão e, posteriormente, pelas instâncias competentes.

2 O texto referido acima é o seguinte: 'O Povo santo de Deus participa também da função profética de Cristo, difundindo o seu testemunho vivo, sobretudo pela vida de fé e de caridade oferecendo a Deus o sacrifício de louvor, fruto dos lábios que confessam o Seu nome (cf. $H b$ 13,15). A totalidade dos fiéis que receberam a unção do Santo (cf. Jo 2, 20 e 27), não pode enganar-se na fé; e esta sua propriedade peculiar manifesta-se por meio do sentir sobrenatural da fé do povo todo, quando este, "desde os Bispos até ao último dos leigos fiéis', manifesta consenso universal em matéria de fé e costumes. Com este sentido da fé, que se desperta e sustenta pela ação do Espírito de verdade, o Povo de Deus, sob a direção do sagrado magistério que fielmente acata, já não recebe simples palavra de homens, mas a verdadeira palavra de Deus (cf. $1 T s$ 2,13), adere indefectivelmente à fé uma vez confiada aos santos (cf. $J d 3$ ), penetra-a mais profundamente com juízo acertado e aplica-a mais totalmente na vida".

3 COMISSÃO TEOLÓGICA INTERNACIONAL, O sensus fidei na vida da Igreja. Brasília: Edições CNBB, 2015, n. 4. 
e prospectivos e seguindo com a análise da contribuição dos leigos e de sua relação com o Magistério, a Teologia e o Ecumenismo. O quarto aborda os critérios para o discernimento do sensus fidei: das disposições necessárias para uma participação autêntica no sensus fidei às aplicações do mesmo à vida da Igreja de hoje.

O presente texto fará, na primeira parte, uma visita ao Documento, com a finalidade de apresentar seus pontos principais, para, em seguida, apresentar sua novidade e expor alguns aspectos a serem aprofundados posteriormente.

\section{Primeira PARTE: O DOCUMENTO}

\section{Objetivo do documento}

O documento não visa explanar de forma exaustiva o sensus fidei, mas esclarecer e aprofundar alguns aspectos importantes desse conceito, a fim de encontrar uma resposta para algumas questões, especialmente aquelas relativas à identificação do autêntico sensus fidei em situações de conflito. ${ }^{4}$

Esse objetivo resultou de questões que surgiram no decorrer da recepção e da aplicação do ensinamento do Concílio sobre o assunto, "particularmente em relação às controvérsias sobre diversos pontos referentes à doutrina e à moral". A partir daí, foram feitas diversas perguntas: "O que exatamente é o sensus fidei, e como se pode identificá-lo? Quais são as fontes bíblicas dessa ideia e qual é a função do sensus fidei na tradição de fé? Qual é a relação do sensus fidei do Magistério eclesiástico do Papa e dos bispos, assim como da teologia? Quais são as condições para um autêntico exercício do sensus fidei? O sensus fidei é algo diferente do que a opinião da maioria dos fiéis em um determinado tempo e lugar? E se isso acontecer, como ele se diferencia? A tantas perguntas é necessário responder, para que a ideia de sensus fidei seja compreendida mais perfeitamente e utilizada com mais confiança na Igreja de hoje". ${ }^{5}$

\footnotetext{
Id., n. 6.

5 Id., n. 5.
} 


\section{Conceituação teológica}

O ponto de partida para entender o sensus fidei é a ação do Espírito Santo nos fiéis (cf. Jo 15,26), que, como dom, faz todos os batizados participarem da missão profética de Jesus Cristo e darem testemunho do Evangelho e da fé dos apóstolos na Igreja e no mundo. O resultado é um instinto para a verdade do Evangelho, o que permite aos fiéis reconhecer quais são a doutrina e a prática cristãs autênticas e como a elas aderir.

O sensus fidei é um instinto ${ }^{6}$ sobrenatural, que tem uma ligação intrínseca com o dom da fé recebido na comunhão da Igreja, e permite aos cristãos cumprir a sua vocação profética. Assim, o sensus fidei refere-se a duas realidades distintas, mas conexas: a Igreja, "coluna e sustentáculo da verdade" (1 Tm 3,15), e cada fiel, que pertence à Igreja devido aos sacramentos da iniciação e que participa da fé e da vida da Igreja, particularmente através da celebração regular da Eucaristia. Assim,

a) O sensus fidei refere-se à aptidão pessoal que tem um fiel, no seio da comunhão da Igreja, para discernir a verdade da fé.

b) O sensus fidei refere-se a uma realidade comunitária e eclesial: o instinto da fé da própria Igreja, por meio do qual ela reconhece o seu Senhor e proclama sua palavra.

c) O sensus fidei, entendido neste sentido, reflete-se no fato de que os batizados convergem em uma adesão vital a uma doutrina de fé ou a um elemento da práxis cristã.

d) Essa convergência (consensus) desempenha um papel vital na Igreja. O consensus fidelium é um critério seguro para determinar se uma doutrina ou uma determinada prática faz parte da fé apostólica.

O documento usa "o termo sensus fidei fidelis para se referir à capacidade pessoal do crente de fazer um discernimento justo em matéria de fé, e o de sensus fidei fidelium para se referir ao instinto de fé da própria Igreja". Ao longo do documento, "dependendo do contexto, sensus fidei irá referir-se a um ou a outro sentido, e, para o segundo significado, será utilizado também o termo de sensus fidelium". ${ }^{7}$

\footnotetext{
6 A palavra "instinto" é usada aqui com o significado de impulso natural inato, independente da razão, que faz a pessoa agir com uma finalidade específica, traduzindo-se em comportamento caracterizado por uma realização estereotipada, padronizada. Esse comportamento é fruto da fé, que torna o agir da pessoa um impulso natural suscitado pela fé.

7 Cf. Id., n. 3.
} 


\section{Fundamentação bíblica e patrística}

A fundamentação bíblica parte da fé, entendida não como "uma simples transmissão de informação religiosa, mas como a proclamação da palavra de Deus e do 'poder de Deus para salvação', que deve ser recebido em toda a verdade $(R m 1,16-17 ; M t 11,15 ; L c 7,22)$ ". ${ }^{8}$ Assim, ela é resposta à Palavra de Deus $(M c 1,15)$. O Antigo e o Novo Testamento mostram claramente que a forma e o conteúdo da fé caminham juntos: "A fé é tanto um ato de fé ou de confiança (fides qua) quanto o que é acreditado ou confessado (fides quae). Os dois aspectos caminham inseparavelmente, pois a confiança é a adesão a uma mensagem que tem um conteúdo inteligível, e a confissão não pode ser reduzida a palavra sem conteúdo, só dos lábios, mas deve vir do coração". 9

A fé é pessoal e eclesial ao mesmo tempo: "As Escrituras mostram que a dimensão pessoal da fé se integra na dimensão eclesial; encontra-se tanto o singular quanto o plural da primeira pessoa: "Nós acreditamos" $\left(G l\right.$ 2,16), e "Eu acredito" (cf. Gl 2,19-20)". ${ }^{10}$ Assim, a fé capacita os fiéis a conhecer a verdade e testemunhá-la: "O Espírito Santo instrui os membros da Igreja para prestar atenção à palavra viva do Espírito, para recebê-la e dar glória a Deus. É pela obediência da fé, que já é um dom do Espírito, que os fiéis são capazes de reconhecer o ensinamento que eles receberam como verdadeiro ensinamento do mesmo Espírito e de responder às instruções dadas a eles". ${ }^{11}$

\section{A história do conceito de sensus fidei}

Do ponto de vista da história, "o conceito de sensus fidelium começou a ser desenvolvido e a ser utilizado de forma mais sistemática no tempo da Reforma, embora o papel decisivo do consensus fidelium, no discernimento e no desenvolvimento da doutrina em matéria de fé e de moral, já tinha sido reconhecido durante os períodos patrístico e medieval"; no entanto, "maior atenção ao papel específico dos leigos a este respeito" foi dada "especialmente a partir do século XIX". ${ }^{12}$

\footnotetext{
8 Cf. Id., n. 9.

9 Cf. Id., n. 10.

${ }^{10}$ Cf. Id., n. 11.

${ }^{11}$ Cf. Id., n. 21.

${ }^{12}$ Cf. Id., n. 22.
} 


\section{a) O período patrístico}

Os Padres e os teólogos dos primeiros séculos consideram que a fé de toda a Igreja era um ponto de referência seguro para discernir o conteúdo da Tradição apostólica, particularmente no contexto de controvérsias, diante de heresias. Eles refutaram as novidades perigosas introduzidas pelos hereges, colocando-os em confronto com o que se mantinha e se fazia em todas as Igrejas. Como exemplo, Jerônimo ${ }^{13}$ (cerca de 345-420) e Epifânio ${ }^{14}$ (cerca de 315-403) usam este argumento para defender a veneração das relíquias e para justificar a virgindade perpétua de Maria. ${ }^{15}$

$\mathrm{O}$ "período patrístico atesta o testemunho dado pelo povo de Deus em seu conjunto como algo que tem um determinado caráter objetivo", argumentando que o povo de Deus, considerado como um todo, "não pode errar em matéria de fé", porque ele recebeu o Espírito Santo que "o capacita a discernir a verdade". ${ }^{16}$ Isso foi decisivo para determinar o cânon das Escrituras, e para a definição das doutrinas principais que diziam respeito, por exemplo, à divindade de Cristo, à virgindade perpétua e à maternidade divina de Maria, à veneração e à invocação dos santos. Um dos casos em que a fé dos leigos desempenhou um papel crucial foi, no século quarto, com a controvérsia com os arianos, condenados pelo Concílio de Niceia, em 325, quando foi definida a divindade de Jesus Cristo. ${ }^{17}$

\section{b) O período medieval}

Nesse período, "os doutores escolásticos reconhecem que a Igreja, a congregatio fidelium, não pode errar em matéria de fé, porque ela é ensinada por Deus, unida a Cristo, sua Cabeça, e que o Espírito Santo habita nela. Tomás de Aquino, por exemplo, leva isso como um ponto de partida, e a razão é que a Igreja universal é governada pelo Espírito Santo, que, conforme prometido pelo Senhor Jesus, lhe ensinará "a verdade plena" (Jo 16,13)". Ele "também tinha um interesse todo particular pelo instinto da fé pessoal de cada fiel, que ele havia perscrutado em relação

\footnotetext{
13 JERÔNIMO, Adversus Vigilantium 5 (CCSL 79C, p. 11-13).

${ }^{14}$ EPIFANEO DE SALAMINA, Panarion hoereticorum, 78, 6; Die griechischen christlichen Schriftsteller der ersten Jahrhunderte, Epiphanius, Bd 3, p. 456.

${ }^{15}$ Cf. COMISSÃO TEOLÓGICA INTERNACIONAL, O sensus fidei na vida da Igreja, n. 23 e 24.

${ }^{16}$ Cf. Id., n. 25.

${ }^{17}$ Cf. Id., n. 26.Cf. $D H 40$.
} 
à virtude teologal da fé". ${ }^{18} \mathrm{O}$ desenvolvimento contínuo entre os fiéis da crença e devoção na Imaculada Conceição é um dos maiores exemplos do papel desempenhado na Idade Média pelo sensus fidelium. ${ }^{19}$

\section{c) O período da Reforma e da pós-Reforma}

O Concílio de Trento, repetidamente apelou para o julgamento de toda a Igreja para defender os artigos controversos da doutrina católica. Seu decreto sobre o sacramento da Eucaristia (1551), por exemplo, invoca especificamente "o sentir universal da Igreja (universum Ecclesiae sensum)". ${ }^{20}$ Melchior Cano ${ }^{21}$ (1509-1560) e Roberto Belarmino ${ }^{22}$ (15421621), para defenderem a fé católica contra os críticos da Reforma, usam o argumento da "universalidade de todos os crentes". ${ }^{23}$

Outros teólogos do período pós-tridentino continuaram a afirmar a infalibilidade da Ecclesia (pelo qual eles entendiam a Igreja toda, incluindo seus pastores) in credendo, mas eles começaram a distinguir de forma bastante clara os papéis da "Igreja docente" e da 'Igreja discente'. A ênfase anterior sobre a infalibilidade 'ativa' da Ecclesia in credendo foi gradualmente substituída por uma ênfase sobre o papel ativo da Ecclesia docens. ${ }^{24}$

${ }_{18}$ TOMÁS DE AQUINO, Summatheologice, IIa IIæ, q. 1, a. 9, s. c.; IIIa, q. 83, a. 5, s. c. (à propósito da liturgia da Missa); Quodl. IX, q. 8 (à propósito da canonização). Cf. também BOAVENTURA, Commentaria in IV librum Sententiarum, d. 4, p. 2, dub. 2 (Opera omnia, Quaracchi, 1889, v. 4, p. 105): "[Fides Ecclesiæmilitantis] quamvis possit deficere in aliquibus personis specialiter, generaliter tamen numquam deficit nec deficiet, iuxta illud Matthæi ultimo: "Ecce ego vobiscum sum usque ad consumationem sæculi"; d. 18, p. 2, a. un. q. 4 (p. 490). Na Summatheologice, IIa IIæ, q. 2, a. 6, ad 3, São Tomás refere esta indefectibilidade da Igreja universal à promessa feita por Jesus a Pedro: a sua fé não poderia falhar ( $L c$ 22,32) (Cf. COMISSÃO TEOLÓGICA INTERNACIONAL, $O$ sensus fidei na vida da Igreja, n. 28).

${ }^{19}$ Cf. COMISSÃO TEOLÓGICA INTERNACIONAL, O sensus fidei na vida da Igreja, n. 27.

${ }^{20}$ DH 1637; ver também DH 1726. Para as expressões equivalentes, ver Yves M.-J. Congar, La Tradition et lestraditions, II. Essai théologique (Paris, Fayard, 1963), p. 82-83 (Cf. COMISSÃO TEOLÓGICA INTERNACIONAL, O sensus fidei na vida da Igreja, n. 30).

${ }^{21}$ De locis theol., livro I, ch. 4 (p. 149): "Non solum Ecclesia universalis, id est, collectio omnium fidelium hunc veritatis spiritum semper habet, sed eundem habent etiam Ecclesiæ principes et pastores".

22 ROBERTO BELARMINO, De controversiis christiance fidei (Venise, 1721), II, I, livro 3, cap. 14: "Et cum dicimus Ecclesiam non posse errare, id intelligimus tam de universitate fidelium quam de universitate Episcoporum, ita ut sensus sit eius propositionis, ecclesia non potest errare, idest, id quod tenent omnes fideles tanquam de fide, necessario est verum et de fide; et similiter id quod docent omnes Episcopi tanquam ad fidem pertinens, necessario est verum et de fide" (p. 73).

${ }^{23}$ Cf. COMISSÃO TEOLÓGICA INTERNACIONAL, O sensus fidei na vida da Igreja, n. 31 e 32 .

${ }^{24}$ Id., n. 33. 


\section{d) O século $X I X$}

Os teólogos começaram a iluminar o papel ativo de toda a Igreja e, especialmente, a contribuição dos fiéis leigos na preservação e transmissão da fé da Igreja. O Magistério confirma implicitamente essa concepção no processo que levou à definição da Imaculada Conceição, em 1854. ${ }^{25}$ Johann Adam Möhler, da Universidade de Tubinga, defende a fé católica contra o racionalismo com este argumento, que ele denominava como "consciência" eclesial da fé. ${ }^{26}$ John Henry Newman estudou o sensus fidei fidelium e foi o primeiro a publicar um tratado inteiramente dedicado a este último tema, intitulado Um Ensaio sobre o Desenvolvimento da Doutrina Cristã, em 1845, adotando a norma de Agostinho, o assentimento geral de toda a Igreja, além de perceber a necessidade de uma autoridade infalível para manter a Igreja na verdade. ${ }^{27}$

Mesmo a definição da infalibilidade do Papa, pela "Constituição Dogmática Pastor Aeternus do Concílio Vaticano I, que definia o magistério infalível do Papa, não ignorou o sensus fidei fidelium; pelo contrário, ela a pressupôs". Assim,

As definições doutrinais ex cathedra do Papa em matéria de fé e moral são irreformáveis 'por si mesmas', e não apenas em virtude do consenso da Igreja (ex sese non autem ex consensu Ecclesiae), não tornou o consensus Ecclesiae supérfluo. O que foi excluído é a teoria segundo a qual tal definição exigiria este consentimento, antecedente ou consequente, como condição para ter autoridade. Em resposta à crise modernista, um decreto do Santo Ofício, Lamentabili (1907), confirmou a liberdade da Ecclesia docens vis-à-vis da Ecclesia discens. O Decreto censurava uma proposta segundo a qual os pastores poderiam ensinar apenas o que os fiéis já acreditassem. ${ }^{28}$

\section{e) O século $X X$}

O século XX deu um impulso ao desenvolvimento do sensus fidei fidelium no contexto de uma teologia da Tradição, de uma eclesiologia renovada e de teologia do laicato. Eles enfatizaram que "a Igreja" não

\footnotetext{
${ }^{25}$ Cf. Id., n. 34.

${ }^{26}$ Cf. Id., n. 35.

${ }^{27}$ Cf. Id., n. 36.

${ }^{28}$ Id., n. 40.
} 
se identifica com seus pastores; que toda a Igreja, pela ação do Espírito Santo, foi o sujeito ou o "órgão" da Tradição; e que os leigos têm um papel ativo na transmissão da fé apostólica. O Magistério assumiu esses desenvolvimentos, por exemplo, na consulta sobre a fé do Povo de Deus na Assunção da bem-aventurada Virgem Maria, e, que, por fim, levou à definição solene. O mesmo encontra-se no Concílio Vaticano II, ao restabelecer e confirmar a doutrina do sensus fidei ${ }^{29}$

O teólogo francês Yves M.-J. Congar (1904-1995) trouxe uma contribuição significativa para o desenvolvimento da doutrina do sensus fidei fidelis e do sensus fidei fidelium ao entender a participação dos leigos na missão profética da Igreja, quando afirma: "A Igreja que crê e ama, isto é, o corpo dos fiéis, é infalível na posse viva da fé, e não em um ato ou em um juízo particular". ${ }^{30}$ O Magistério também o leva em conta, como demonstram o Vaticano II, ao desenvolver esta doutrina na Lumen Gentium 12 e na Dei Verbum 8, e o Papa João Paulo II, na sua Exortação Pós-Sinodal Familiaris Consortio (1981), ao considerar a relação que "o senso sobrenatural da fé" tem com o "consenso dos fiéis" e a opinião da maioria, determinada por pesquisas sociológicas e por estatísticas. O sensus fidei, escreve ele, "não consiste só ou necessariamente com o consenso dos fiéis". É tarefa dos pastores da Igreja "promover o sentido da fé em todos os fiéis, examinar e julgar com autoridade a autenticidade de suas expressões, e formar os fiéis para um discernimento evangélico sempre mais maduro". ${ }^{31}$

\section{$5 \quad$ A natureza do sensus fidei}

O capítulo segundo apresenta a natureza do sensus fidei. Ele é "como instinto da fé", "é uma espécie de instinto espiritual que capacita

${ }^{29}$ Cf. Id., n. 41.

${ }^{30}$ Ver CONGAR, Jalons pour une Théologie du Laïcat, capítulo 6. O esquema se encontra no Prefácio da terceira edição da Via Media de Newman (1877).

31 João Paulo II, Exortação apostólica Familiaris consortio (1981), n. 5. Em sua Instrução sobre a Vocação eclesial do teólogo, Donum veritatis (1990), a Congregação para a Doutrina da Fé combate a identificação da "opinião de um grande número de cristãos" com o sensusfidei: "Este é uma propriedade da fé teologal" e "um dom de Deus, que faz aderir pessoalmente à Verdade", de sorte que o cristão crê o que a Igreja crê. De fato, é necessário sublinhar que nem todas as opiniões dos fiéis tem necessariamente a fé por origem, e que um grande número de pessoas são influenciadas pela opinião pública, assim como fez o Concílio, "a relação indissolúvel entre sensus fidei e orientação do povo de Deus por parte do Magistério dos pastores" (n. 35) (Cf. COMISSÃO TEOLÓGICA INTERNACIONAL, O sensus fidei na vida da Igreja, n. 45, 46 e 47). 
o crente a julgar de forma espontânea se algum ensino particular ou determinada prática está ou não em conformidade com o Evangelho e com a fé apostólica", que decorre da própria virtude da fé e é uma propriedade dela. ${ }^{32}$ Ele, o sensus fidei fidelis, "não é um conhecimento reflexivo dos mistérios da fé, que desenvolve conceitos e utiliza procedimentos racionais para chegar às suas conclusões", mas é "uma reação natural, imediata e espontânea, comparável a um instinto vital ou a uma espécie de "faro", pelo qual o crente adere espontaneamente ao que está conforme a verdade da fé e evita o que se opõe". ${ }^{33}$

Como deriva da virtude teologal da fé, o sensus fidei fidelis é infalível em si mesmo quanto ao seu objeto, a verdadeira fé, e cresce em proporção ao desenvolvimento da virtude da fé, havendo, por isso, "uma interação vital entre o sensus fidei e o modo como cada fiel vive a fé em diversos contextos de sua vida pessoal", o que "permite ver mais claramente o valor e as limitações de uma determinada doutrina, e propor caminhos para uma formulação mais adequada. É por isso que aqueles que ensinam em nome da Igreja devem prestar muita atenção à experiência dos fiéis, especialmente a dos leigos que se esforçam para colocar em prática os ensinamentos da Igreja em áreas onde eles possuem experiência e conhecimento específicos". ${ }^{34}$

As manifestações do sensus fidei fidelis na vida pessoal dos fiéis são três: "1) discernir se um ensinamento particular ou se uma determinada prática que ele encontra na Igreja é coerente ou não com a verdadeira fé pela qual ele vive em comunhão com a Igreja;2) distinguir na pregação o essencial do secundário; 3) identificar e colocar em prática o testemunho a dar de Jesus Cristo no contexto histórico e cultural particular em que ele vive". 35

\section{$6 \quad$ O sensus fidei fidelium na vida da Igreja}

O capítulo terceiro aborda vários aspectos do sensus fidei fidelium: o seu papel no desenvolvimento da doutrina e da prática cristãs; as relações entre o sensus fidei e o Magistério e entre o sensus fidei e teologia; alguns aspectos ecumênicos do sensus fidei.

\footnotetext{
${ }^{32}$ Cf. COMISSÃO TEOLÓGICA INTERNACIONAL, O sensus fidei na vida da Igreja, n. 49.

${ }^{33}$ Cf. Id., n. 54.

${ }^{34}$ Cf. Id., n. 55, 57 e 59.

${ }^{35}$ Cf. Id., n. 60-65.
} 
O papel do desenvolvimento da doutrina e da prática cristã do sensus fidei tem como ponto de partida a responsabilidade da Igreja inteira, hierarquia e leigos juntos, "pela revelação contida nas Sagradas Escrituras e na Tradição apostólica viva", que é "confiada à Igreja", isto é, o "povo santo todo, unido a seus pastores", pois os fiéis não são apenas os destinatários passivos do que a hierarquia ensina e os teólogos explicitam, mas eles são, ao contrário, sujeitos vivos e ativos no seio da Igreja. Por isso, a fé e o sensus fidei não estão apenas ancorados no passado, o aspecto retrospectivo, mas também estão orientados em direção ao futuro, o aspecto prospectivo, o que exige um processo de discernimento. Tal processo exige tempo para chegar a alguma conclusão, onde os fiéis em geral, os pastores e os teólogos têm cada qual o seu papel a desempenhar, a fim de atingir um esclarecimento do sensus fidei e realizar um verdadeiro consensus fidelium, uma conspiratio pastorum et fidelium". ${ }^{36}$

Os leigos contribuíram, desde o início do cristianismo, com o desenvolvimento da fé cristã através do testemunho da fé apostólica e em decisões sobre a fé. Houve momentos em que o povo de Deus, em particular os leigos, tenha sentido intuitivamente em que direção andaria o desenvolvimento da doutrina, mesmo quando teólogos e bispos estavam divididos sobre uma questão. Em outros momentos, quando a Igreja chegou a uma definição, a Ecclesia docens havia claramente "consultado" os fiéis, e ela indicava o consensus fidelium como que um dos argumentos que legitimava a definição. ${ }^{37}$

Os leigos também colaboram com o desenvolvimento moral da Igreja, pois, em algumas áreas, o ensinamento da Igreja desenvolveu-se como resultado da descoberta das exigências requeridas diante de novas situações vividas por eles. A reflexão dos teólogos e o julgamento do Magistério foram, então, baseados na experiência cristã já iluminada pelas intuições dos fiéis leigos. É o caso da abertura da Igreja aos problemas sociais, que se manifesta especialmente na Carta Encíclica Rerum Novarum do Papa Leão XIII (1896), foi o resultado de uma lenta preparação na qual os "pioneiros sociais" leigos, homens de ação e de pensamento, desempenharam um papel principal. $^{38}$

\footnotetext{
${ }^{36}$ Cf. Id., n. 66, 69 e 71.

${ }^{37}$ Cf. Id., n. 72.

${ }^{38}$ Cf. Id., n. 73.
} 
As relações entre o sensus fidei e o Magistério acontece quando o Magistério "escuta o sensus fidelium, pois, em matéria de fé, os batizados não podem ser passivos", e, por isso, eles "não só têm o direito de serem ouvidos, mas também as suas reações ao que está sendo proposto como pertencente à fé dos Apóstolos devem ser consideradas com maior seriedade, porque é por toda a Igreja que a fé apostólica é sustentada no poder do Espírito. O Magistério não tem a responsabilidade exclusiva. Ele deve, portanto, referir-se ao senso da fé de toda a Igreja" e ele "precisa ter formas por meio das quais possa consultar os fiéis". O documento situa a liturgia como o lugar particular onde acontece a "ligação entre o sensus fidelium e o Magistério", pois a Eucaristia plasma e molda o sensus fidelium, e isso contribui fortemente para a formulação e o aperfeiçoamento das expressões verbais de fé, pois é aí que o ensinamento dos bispos e dos Concílios é, em última análise, "recebido" pelos fiéis", de acordo com a fórmula lex orandi, lex credendi. ${ }^{39}$

De outro lado, o Magistério alimenta, discerne e julga o sensus fidelium, pois "o julgamento sobre a autenticidade deste pertence, em última análise, não aos próprios fiéis nem à teologia, mas ao Magistério". ${ }^{40}$

As relações entre o sensus fidei e a teologia são duas: os teólogos dependem e refletem o sensus fidei. Dependem, porque o sensus fidelium constitui um fundamento e um locus para o seu trabalho, além do que a fé que eles estudam e explicam vive no povo de Deus e "os teólogos ajudam os fiéis a expressar o sensus fidelium autêntico, lembrando-lhes as linhas essenciais da fé e ajudando-os a evitar desvios e confusões causadas pela influência de elementos imaginários provenientes de outros lugares". Os teólogos refletem sobre o sensus fidelium, porque ele não se identifica pura e simplesmente com a opinião da maioria dos batizados em uma determinada época, e, por isso, a teologia deve fornecer princípios e critérios que permitam realizar um discernimento, especialmente por parte do Magistério. Também a teologia ajuda os fiéis a conhecer com clareza e precisão o sentido autêntico das Escrituras, o verdadeiro alcance das definições conciliares, os conteúdos próprios da Tradição, bem como as questões que permanecem em aberto. ${ }^{41}$

\footnotetext{
${ }^{39}$ Cf. Id., n. 74 e 75.

${ }^{40}$ Cf. Id., n. 77.

${ }^{41}$ Cf. Id., n. 81,83 e 84.
} 


\section{As disposições necessárias para uma participação autêntica no sensus fidei}

O capítulo quarto do documento mostra que não há uma única disposição, mas sim um conjunto de disposições, influenciado por fatores eclesiais, espirituais e éticos, os quais devem ser levados conjuntamente. Estas disposições, por sua vez, podem ser utilizadas como critérios para discernir o autêntico sensus fidei. E são as seguintes:

a) A participação na vida da Igreja: Uma pertença formal à Igreja não é suficiente, mas uma participação ativa na vida da Igreja significa oração constante (cf. 1Ts 5,17), participação ativa na liturgia, especialmente a Eucaristia, recepção regular do sacramento da reconciliação, discernimento e exercício de dons e carismas recebidos do Espírito Santo, e participação ativa na missão da Igreja e na sua diakonia. Isso supõe a aceitação da doutrina da Igreja em matéria de fé e moral, a vontade de seguir os mandamentos de Deus e a coragem de exercer a correção fraterna como também de submeter-se. Além disso, uma solidariedade ativa com a Igreja, que vem do coração, um sentimento de fraternidade com outros membros fiéis e com toda a Igreja, e, disto, um instinto para perceber quais são as necessidades da Igreja e os perigos que a ameaçam. É o sentire cum Ecclesia, necessário para todos os fiéis; ela une todos os membros do povo de Deus em sua peregrinação. Ela é a chave do seu "caminhar juntos". ${ }^{42}$

b) A escuta da Palavra de Deus: É necessária uma escuta profunda e atenta da Palavra de Deus, que é transmitida de geração em geração na comunidade de fé, e uma resposta do coração (cf. 2 Cor 1,20 ). A coerência com a Escritura e com a Tradição é o indicador principal de tal escuta. Também é necessário estudar cientificamente a Bíblia e o testemunho da Tradição.

c) A abertura à razão: Como a fé e a razão caminham juntas, é preciso aceitar o papel próprio da razão na sua relação com a fé.

d) A adesão ao Magistério: É necessária a atenção ao Magistério da Igreja e a vontade de escutar o ensinamento dos pastores da Igreja, como um ato de liberdade e profunda convicção.

${ }^{42}$ Cf. Id., n. 89 e 90. 
e) A santidade - a humildade, a liberdade e a alegria: A santidade é a vocação de toda a Igreja e de cada crente. Ser santo significa pertencer fundamentalmente a Deus em Jesus Cristo e na sua Igreja, ser batizado e viver a fé no poder do Espírito Santo. Constata-se que, na história da Igreja, os santos são os portadores da luz do sensus fidei. Porque ele basicamente requer imitatio Christi (cf. $F l$ 2,5-8), a santidade implica essencialmente humildade. Essa humildade é oposta à hesitação ou à timidez; ela é um ato de liberdade espiritual. E um sinal claro da santidade é "paz e alegria no Espírito Santo" ( $R m$ 14,17; cf. $1 T s$ 1,6). Esses dons se manifestam antes de tudo em um nível espiritual, e não psicológico ou emocional. É a paz do coração e alegria tranquila daquele que encontrou o tesouro da salvação, a pérola de grande valor (cf. $M t$ 13,44-46).

f) A busca da edificação da Igreja: A manifestação autêntica do sensus fidei contribui para edificar a Igreja como um só corpo, sem nutrir dentro dela divisões ou particularismos.

\section{Aplicações práticas do sensus fidei}

Os aspectos ecumênicos do sensus fidei não estão incluídos nas aplicações práticas, mas podem ser abordados aqui, pois "duas questões específicas relativas ao sensus fidelium surgem no contexto do diálogo ecumênico, no qual a Igreja Católica está empenhada de forma irreversível": primeiro, não se pode considerar como verdadeiras e vinculantes apenas as doutrinas que tenham obtido o consentimento comum de todos os cristãos e que expressam o sensus fidelium, pois os participantes católicos não podem suspender o próprio consentimento às doutrinas reconhecidas que a Igreja Católica possui como próprias; segundo, que os cristãos separados participam e contribuem de alguma forma ao sensus fidelium e que o diálogo ecumênico ajuda a aprofundar e a esclarecer a compreensão que ela mesma tem do Evangelho. ${ }^{43}$

A primeira aplicação é quanto à religiosidade popular, pois esta provém do sensus fidei e a manifesta, por isso deve ser respeitada e promovida, e é a primeira e fundamental forma de inculturação da fé. ${ }^{44}$

\footnotetext{
${ }^{43}$ Cf. COMISSÃO TEOLÓGICA INTERNACIONAL, O sensus fidei na vida da Igreja, n. 86.

${ }^{44}$ Cf. Id., n. 110-112.
} 
Outra aplicação é a relação entre o sensus fidei e a opinião pública. Sem dúvida, ela é uma das questões mais delicadas nos dias de hoje, pois a opinião pública implica a maioria, tanto dentro quanto fora da Igreja. ${ }^{45}$

Hoje, ouve-se muito mais frequentemente a voz dos leigos na Igreja, com posições diversas. Mas as novas redes de comunicação, seja dentro ou fora da Igreja, exigem novas formas de atenção e crítica, bem como a renovação dos métodos de discernimento, pois algumas influências provenientes de grupos com interesses particulares não são compatíveis, ou não inteiramente, com a fé católica, além de haver pressões para enfraquecer o papel da fé no debate público ou para adaptar a doutrina cristã tradicional aos interesses e às opiniões modernas. ${ }^{46}$ Assim, não se pode pura e simplesmente identificar o sensus fidei à opinião pública ou da maioria: o sensus fidei não pode assimilar a opinião pública da sociedade como um todo. A fé, não a opinião, é o ponto de referência ao qual é necessário prestar atenção. $\mathrm{Na}$ história do povo de Deus, muitas vezes não foi a maioria, mas uma minoria que realmente viveu a fé e a testemunhou. Por isso, é particularmente importante discernir e escutar as vozes dos "pequeninos que creem" (Mc 9,42).

Outra aplicação diz respeito aos meios para consultar os fiéis. É um direito dos fiéis serem consultados. A prática não é novidade na Igreja. ${ }^{47}$ Depois do Concílio Vaticano II, foram estabelecidos vários meios institucionais pelos quais os fiéis possam ser ouvidos de maneira mais formal. Esses são os Concílios particulares, aos quais os presbíteros assim como outros seguidores de Cristo podem ser convidados (cânon $443, \S 4)$; os sínodos diocesanos, aos quais o bispo diocesano pode convidar os membros do laicato (cânon 443, § 4); o conselho pastoral de cada diocese, que se compõem de "fiéis em plena comunhão com a Igreja Católica, clérigos, membros de institutos de vida consagrada, ou principalmente leigos" (Cânon 512, § 1) e conselhos pastorais das paróquias, "nos quais os fiéis ajudam a promover a ação pastoral, juntamente com os que participam do cuidado pastoral da paróquia em virtude do próprio ofício" (cânon 536, § 1) (n. 125).

\footnotetext{
${ }^{45}$ Cf. Id., n. 113.

${ }^{46}$ Cf. Id., n. 116 e 117.

${ }^{47}$ Cf. Id., n. 120 e 122.
} 


\section{SEgundA PARTE: SOBRE O DOCUMENTO}

Esta segunda parte apresenta alguns aspectos sobre o Documento apresentado na parte, anterior, refletindo sobre a sua novidade e sobre alguns aspectos que deveriam ser aprofundados neste seu processo de recepção. Especialmente o segundo item é totalmente despretensioso, pois dependerá da forma como ele será recebido pela Igreja e pela reflexão teológica de hoje, processo apenas iniciado.

\section{A novidade do Documento}

Podem-se apontar duas novidades de fundo, presentes no Documento, que correspondem ao elã teológico presente nos documentos do Vaticano II: a pneumatologia e a teologia do laicato do Vaticano II.

Falar de sensus fidei/sensus fidelium supõe a ação do Espírito Santo na Igreja, o que aponta para o modo como o Vaticano II compreendeu e expressou a presença do Espírito Santo na Igreja. Ele entendeu o mistério de Deus de forma trinitária e, por consequência, a própria Igreja, o que comporta, além disso, a recíproca implicação epistemológica e metodológica entre teologia trinitária e eclesiologia, ou seja, entre Trindade e Igreja. ${ }^{48}$ No Concílio Ecumênico Vaticano II, é encontrada de forma clara a afirmação da presença e da ação do Espírito Santo na Igreja, especialmente com a Lumen Gentium, por meio da citação da frase de Cipriano no número 4, e com a Unitatis Redintegratio, no número 2 , e, por isso, a Igreja passou a ser entendida como imagem da comunhão (communio) trinitária. ${ }^{49}$

Afirmar que todos os fiéis não erram no sentido da fé implica em reconhecer a teologia do laicato e levá-la a sério. O tema do leigo revelou-se como uma das grandes novidades teológicas do Vaticano II, que, desse modo, recuperou a compreensão teológica dos fiéis leigos na Igreja e explicitou claramente a sua identidade e a sua missão na Igreja e no mundo. Esse tema teve uma grande repercussão na vida eclesial desde então e encontrou acolhida positiva na reflexão teológica e na ação pastoral, superando uma visão meramente funcional do laicato e reafirmando a sua vocação eclesial como fruto do Batismo (cf. Lumen Gentium, n. 31).

${ }^{48}$ Cf. M. NARO, Trinità e Chiesa. In: G. CALABRESE; P. GOYRET; O. F. PIAZZA (ed.), Dizionario di Ecclesiologia. Roma: Città Nuova, 2010, p. 1465-1469.

${ }^{49}$ Cf. W. KASPER, Chiesa Cattolica. Essenza - Realtà - Missione. Brescia: Queriniana, 2012, p. 129. 


\section{Pontos a serem aprofundados}

Ainda há alguns aspectos que deverão ser aprofundados, porquanto o documento se restringiu a citar alguns temas importantes, mas que, devido ao objetivo do próprio Documento e, também, por falta de espaço, não foram abordados com maior extensão e profundidade. Entre esses pontos, podem citar-se os seguintes:

a) A relação entre o sensus fidei e a opinião pública, pois ele sofre o risco de ser confundido como mera expressão do pensamento da maioria ou de poder apontar para uma maioria numérica frente a um pequeno número de pessoas, sendo compreendido de forma quantitativa. É necessário fugir dessa confusão, visto que maioria não significa necessariamente posse da Verdade, e, por isso, já necessariamente sensus fidei. Nesta questão, estão envolvidas a própria Revelação, enquanto fonte da qual a Igreja vive, e a recepção da mesma pelos fiéis.

b) A relação entre sensus fidei e cultura, que passa por uma mudança de época. A cultura está profundamente afetada pelo fenômeno da globalização, que incide em todos os campos da vida humana, provocando o relativismo e o democratismo, trazendo uma crise do sentido "que dá unidade a tudo que existe e nos sucede na experiência, e que os cristãos chamam de sentido religioso". ${ }^{50}$ A propósito, pode ser lembrada a afirmação do Papa Paulo VI na Evangelii Nuntiandi sobre a relação entre evangelização e cultura:

O Evangelho e, consequentemente, a evangelização não se identificam por certo com a cultura, e são independentes em relação a todas as culturas. E, no entanto, o reino que o Evangelho anuncia é vivido por homens profundamente ligados a uma determinada cultura, e a edificação do reino não pode deixar de servir-se de elementos da civilização e das culturas humanas. O Evangelho e a evangelização independentes em relação às culturas, não são necessariamente incompatíveis com elas, mas suscetíveis de as impregnar a todas sem se escravizar a nenhuma delas (Evangelii Nuntiandi, n. 20).

${ }^{50}$ CONSELHO EPICOPAL LATINO-AMERICANO, Documento de Aparecida. Texto conclusivo da V Conferência Geral do Episcopado Latino-Americano e do Caribe. Brasília e São Paulo: Edições CNBB, Paulus e Paulinas, 2007, n. 34 e 37. 
c) Outro aspecto que merece uma abordagem mais profunda é a dimensão ecumênica do sensus fidei e sensus fidelium. Sendo o movimento ecumênico, a busca da unidade dos cristãos através do diálogo fraterno, o sentido da fé adquire relevância, pois, para resguardar a "unidade nas coisas necessárias" e conservar a "devida liberdade, tanto nas várias formas de vida espiritual e de disciplina, quanto na diversidade de ritos litúrgicos e até mesmo na elaboração teológica da verdade revelada" (cf. Unitatis Redintegratio, n. 4), impõe-se um discernimento que só poderá ser feito a partir da grande Tradição da Igreja de Jesus Cristo.

d) A relação entre sensus fidei e a formação dos fiéis, visto que, nos dias de hoje, grande parte destes carecem de uma formação religiosa adequada, tendo como consequência a falta de conhecimento básico das verdades da fé católica, o que resultaria em incapacidade dos fiéis para julgar temas referentes à fé cristã. Por isso, frequentemente se repete a necessidade de proporcionar formação doutrinal, sem se esquecer de que ela seja acompanhada de uma dimensão existencial adequada, como se constata em diversos documentos do CELAM. ${ }^{51}$

e) A vida de fé dos fiéis católicos diante da secularização da fé, que leva muitos a não conseguir realizar um adequado ato de fé, livre e pessoal, trazendo ao debate a relação entre a fé implícita e a fé explícita, especialmente, no agir moral e na recepção dos sacramentos, particularmente, no consentimento dado no sacramento do matrimônio.

\section{Conclusão}

O conteúdo do Documento apresenta uma reflexão atualizada e rica sobre o tema do sensus fidei/sensus fidelium na vida da Igreja, trazido à luz pelo Vaticano II, e que necessita ser refletido a fim de poder ser bem compreendido e utilizado na vida da Igreja, especialmente na relação entre a doutrina e a ação pastoral.

\footnotetext{
${ }^{51}$ Como exemplo, vale citar CONSELHO EPISCOPAL LATINO-AMERICANO. Documento de Puebla, Petrópolis: Vozes, CONSELHO EPICOPAL LATINO-AMERICANO, Documento de Aparecida. Texto conclusivo da V Conferência Geral do Episcopado Latino-Americano e do Caribe. Brasília e São Paulo: Edições CNBB, Paulus e Paulinas, 2007, n. 34 e 37.
} 


\section{Referências}

BOAVENTURA. Opera omnia. Quaracchi, 1889. v. 4.

COMISSÃO TEOLÓGICA INTERNACIONAL. O sensus fidei na vida da Igreja. Brasília: Edições CNBB, 2015.

CONGAR, Y. Jalons pour une Théologie du Laïcat.

CONSELHO EPICOPAL LATINO-AMERICANO, Documento de Aparecida. Texto conclusivo da V Conferência Geral do Episcopado Latino-Americano e do Caribe. Brasília e São Paulo: Edições CNBB, Paulus e Paulinas, 2007.

EPIFANEO DE SALAMINA. Panarion hoereticorum, 78, 6.

Bd 3.

. Die griechischen christlichen Schriftsteller der ersten Jahrhunderte, Epiphanius,

JERÔNIMO. Adversus Vigilantium 5 (CCSL 79C).

KASPER, W. Chiesa Cattolica. Essenza - Realtà - Missione. Brescia: Queriniana, 2012.

NARO, M. Trinità e Chiesa. In: CALABRESE, G.; GOYRET, P.; PIAZZA, O. F. (ed.). Dizionario di Ecclesiologia. Roma: Città Nuova, 2010. p. 1465-1469.

PAPA JOÃO PAULO II. Exortação apostólica Familiaris consortio (1981). . Instrução sobre a Vocação eclesial do teólogo, Donum veritatis (1990).

ROBERTO BELARMINO. De controversiis christiance fidei (Venise, 1721), II, I. TOMÁS DE AQUINO. Summa theologiae.

Recebido: $18 / 03 / 2015$

Avaliado: 20/03/2015 